\title{
O lirismo gauche de Afonso Henriques Neto: reflexões sobre a poesia brasileira contemporânea
}

Marleide Anchieta de Lima ${ }^{1}$

sim: desfaço o que faço ou não faço: pois sei pouco, três ou quatro poetas, versos mancos aos trancos e barrancos por isso flutuo, disfarço. (HENRIQUES NETO, 2001, p.233)

Nas últimas décadas, é notório o domínio dos meios de comunicação de massa que, muitas vezes, privilegiam a banalidade dos discursos e das imagens, valorizando o imediatismo, o apelo simplista e uma exacerbada visualidade. Nesse contexto, a poesia, assim como outras formas literárias, poderia estar condenada ao desaparecimento, já que é difícil competir com a hegemonia capitalista e com os avanços tecnológicos. Contudo, o que se percebe é uma extensa e diversificada produção poética que fortalece seu papel crítico e expressivo na cultura brasileira contemporânea.

Alguns poetas apostam em recursos midiáticos na criação e divulgação de seus trabalhos, produzindo poemas holográficos, "poema clip", "vídeo poesia tridimensional", coleções de poesia em CDs ou até mesmo leituras teatralizadas em eventos, como menciona a crítica Heloísa Buarque de Hollanda (1998, p.14). Outros se

\footnotetext{
${ }^{1}$ Doutoranda em Literatura Comparada Universidade Federal Fluminense
} 
afastam da circulação mercadológica e investem nas formas, nas expressões, no jogo inventivo da palavra escrita de forte inserção nos centros culturais e nas instituições acadêmicas. Há ainda, aqueles que transportam, para o ato de descrever, suportes visuais e sonoros de outras linguagens e, dessa maneira, articulam a poesia com as “performances, com as artes plásticas, com a fotografia, com a música, com o trabalho corporal" (Hollanda, 1998, p.14).

Sem estabelecer critérios de qualidade ou de valor literários para esse ou aquele modo de divulgação, ressalta-se a variedade de propostas na conjuntura atual. Não é à toa que a autora citada diz que "a produção poética contemporânea se mostra como uma confluência de formas e temáticas sem estilos ou referências definidas" (Hollanda, 1998, p.11). Nesse sentido, pode-se caracterizar o momento como um entrelaçamento de dicções diversas e de traços artísticos plurais, em que os poetas tentam inscrever a sua própria voz.

Sem dúvida, vive-se diante de um cenário múltiplo no qual surgem novos poetas, ratificando um impulso criativo no recente panorama literário brasileiro. Apesar dessa diversidade, opta-se nesse artigo por investigar especificamente a obra de Afonso Henriques Neto - poeta brasileiro que iniciou sua trajetória literária em 1972 -, pois ele nos permite visualizar, pelo menos em alguns aspectos, a escrita caleidoscópica dessa produção contemporânea.

Mobilizando-se pelas tendências da poesia brasileira, Afonso Henriques questiona incessantemente o contexto que o cerca, seus pares literários e sua genealogia poética, produzindo, através da escrita, sentidos que o conduzem a um caminho diferenciado, sem negar a presença do outro, inserida em sua pele, em sua história e em sua linguagem. Atento às palavras de Carlos Drummond de Andrade, poeta com o qual partilhou o chão de Minas Gerais, compreende a arte de construir um lirismo gauche e 
articula uma proposta distanciada de enquadramentos em periodizações, escolas e modos literários.

Drummond, o poeta das sete faces, escreveu os célebres versos: “Quando nasci, um anjo torto/ desses que vivem na sombra/ disse: Vai Carlos ser gauche na vida" (Andrade, 1996, p.5). O termo gauche é palavra de origem francesa, cujo significado traduz-se como esquerdo, torto, desajeitado, aquele que está à margem (Le Robert, 2007, p.323). Esses sentidos adquiriram uma dimensão singular na obra drummondiana, assinalando uma poeticidade imprevista, captada por olhos que perceberam outras versões de mundo, estejam elas na memória da infância em Itabira, nos poemas de resistência em A Rosa do Povo, na forte presença objectual em Lição de Coisas ou nas especulações metafísicas de Claro Enigma. Sobre isso, comenta o crítico Alcides Villaça, no livro Passos de Drummond, ao apontar que o poeta cria uma "identidade complexa de quem está sempre fora de alguma expectativa" (Villaça, 2006, p.35). Essa observação sublinha a transitividade, ou melhor, o caráter móvel do discurso drummondiano.

Se em Drummond o termo gauche explicita a ruptura de expectativas e as várias faces e fases do poeta, em Afonso Henriques esse termo implicará também um trabalho que rompe propostas fixas, já que pressupõe uma postura deslocada, ora da tradição, ora em relação aos poetas de seu tempo. Nota-se, portanto, que Afonso Henriques assimila a voz de Drummond, fortalecendo os efeitos de um lirismo cujas marcas são a imprevisibilidade e o deslocamento, pois as oscilações formais e temáticas de sua poesia apontam para uma obra pouco suscetível a rótulos, como se evidenciará ao longo desse artigo.

O próprio Carlos Drummond de Andrade, ao entrar em contato com a obra de Afonso Henriques Neto, analisou os traços peculiares na personalidade poética de seu conterrâneo. Destacou também a inadequação do poeta a estilos uniformes, indicando o 
caráter oscilatório de sua escrita por entre as linhas de força que delineiam potencialidades críticas e estéticas. Em 1976, Drummond comentou que os poemas do autor mencionado, "mesmo quando aparentemente desarticulados", expressam uma dicção livre "sem excluir as graças e os luxos do verso belo em si" (Apud Henriques Neto, 2001, p. 256), ressaltando que

Sua personalidade poética é indiscutível - tanto mais quanto, chegando após duas gerações de poetas de alta qualidade, ela se afirma independente da influência dos grandes próximos que o rodeiam.

E é tanto mais curioso essa personalidade quanto ela se permite ondular entre formas simplesmente modernas de poesia e formas de nítida vanguarda, como a experimentar forças nos dois setores. (Apud Henriques Neto, 2001, p.256).

O comentário drummoniano ${ }^{2}$ reitera a proposta lírica de Afonso Henriques Neto, em que convivem várias faces da poesia, intercalando a consonância e a dissonância, a referência e a abstração, a palavra e o silêncio. Essa ambivalência poética exprime a tentativa de desestabilizar fronteiras em todas as suas instâncias, sejam elas literárias, sociais ou culturais e, dessa forma, construir caminhos singulares.

De acordo com Cacaso, autor dos anos 70, a obra de Afonso Henriques sugere "um inventário de ruínas - familiares, ideológicas, pessoais"33 (Apud Henriques Neto, 2001, p.258). A visão de Cacaso é, de certa forma, reiterada pelo também poeta Armando Freitas Filho ao mencionar que a referida obra apresenta "a enumeração mágica do caos" (Freitas Filho, 2005, p.186). Ambos os autores destacam os efeitos inseridos nessa

\footnotetext{
${ }^{2}$ Esse comentário de Carlos Drummond de Andrade acerca do projeto poético de Afonso Henriques insere-se na penúltima parte da obra Ser infinitas palavras, intitulada "Alguns fragmentos sobre Afonso Henriques", na qual há trechos de cartas, ensaios e prefácios redigidos por críticos literários e poetas, observando as obras do referido autor.

${ }^{3}$ Ressalta-se que o termo "ruínas", citado pelo poeta Cacaso, não remete ao conceito benjaminiano como se poderia supor, mas aponta os efeitos produzidos pela capacidade de deslocamento de Afonso Henriques diante de concepções subjetivas, sociais ou culturais.
}

Brasiliana - Journal for Brazilian Studies. Vol. 3, n.1 (Jul. 2014). ISSN 2245-4373. 
poética à "beira do abismo" (Freitas Filho, 2005, p.186), que assinalam a experiência do sujeito em face da instabilidade espaço-temporal e sociocultural de "uma vivência quase irrepresentável" (Sussekind, 2005, p.60). Nesse sentido, o poeta em estudo parece identificar na catalogação de imagens instáveis e caóticas do contexto contemporâneo, ora privilegiando a referencialidade, ora os aspectos oníricos, seu modo de desterritorialização ${ }^{4}$ diante da poesia brasileira.

No processo de se desterritorializar, cada poema tenta inventariar o que se recolhe no movimento deambulatório do poeta em meio às ruínas de um tempo, de modo a escavá-las, selecionando os vestígios de história e de experiências subjetivas e coletivas inscritas através da palavra poética. Sobre isso, Afonso Henriques poetiza: "vamos aos confins da lenda/ da anemia do caos da iluminação/ até que não reste nenhum poema/ até que todos os versos se tornem/ o germe do chão/ o esqueleto do vento/ a primavera completa" (Henriques Neto, 1995, p.72). Num poema sem título, que inicia o livro Abismo com violinos editado em 1995, o poeta lista imagens que indicam um "inventário de ruínas", dentre as quais se destacam "programa de escombros", "estrada para a danação", "esmagado no escuro", "relógios enguiçados", "sóis mecânicos", "implume desencantada" (Henriques Neto, 1995, p.5). Além disso, o poema desenha o trajeto lírico proposto pelo escritor frente a um espaço de caos:

Não ir onde o programa de escombros irrevela

\footnotetext{
${ }^{4}$ A crítica literária Flora Sussekind analisa que a poesia brasileira contemporânea, sobretudo o eixo Rio de Janeiro São Paulo, tende a apresentar modos diferenciados de desterritorialização, que se processam com base na experiência de cada poeta diante da vivência citadina dos tempos atuais. Ela explica que esse conceito foi cunhado por Gilles Deleuze e Félix Guattari em $O$ anti-Édipo, mas que, para pensar nossa poesia, ela o submeteu a desdobramentos distintos e a um contexto particular, "o das relações entre o imaginário literário urbano e processo cultural no Brasil contemporâneo" (Sussekind, 2005, p.66).
}

Brasiliana - Journal for Brazilian Studies. Vol. 3, n.1 (Jul. 2014). ISSN 2245-4373. 
(esta é uma estrada

para a danação)

perseguir a seiva até o fundo do fruto

grito de flor esmagado no escuro

mas esquecer

(esta é uma estrada

além da flora do nada)

relógios enguiçados

ganindo sonho obscuro

sóis mecânicos sais

agônicos

este o fogo da estrada

implume desencantada

sem palavra

desinvenção

(Henriques Neto, 1995, p.5)

O poema apresenta-se como enumeração de objetivos e imagens. Os verbos no infinitivo "ir", "perseguir" e "esquecer" indicam as pretensões do sujeito diante de uma estrada que se apresenta como abissal. Há a opção de não se trilhar o caminho das ruínas ("não ir onde o programa de escombros/ irrevela"), a fim de seguir os rastros vitais que ainda existem nessa paisagem - "perseguir a seiva até o fundo do fruto". O verso "grito de flor esmagado no escuro" expressa a intensidade de um clamor asfixiado que tenta emergir na vitalidade da poesia. Os recursos sinestésicos empregados mobilizam principalmente 
a visão e a audição e sugerem a atmosfera que paira sobre aquele que observa os possíveis caminhos e seus vestígios.

Os parênteses surgem no texto como se indicassem as direções da estrada: "para a danação", "além da flora do nada". Diante disso, há a impressão de uma estrada sem possibilidades de retorno e, concomitantemente, projeta-se a ideia de um espaço ilimitado. Os dêiticos "esta" e "este" demonstram a proximidade do sujeito diante do elemento observado, ou seja, um trajeto de escombros inventariados.

Nesse contexto, elementos artificiais - "relógios enguiçados", "sóis mecânicos" aparecem marcados por sons e imagens inquietantes, frutos de uma engrenagem que não se ajusta a modelos cartesianos e de propostas que se rasuram ("relógios enguiçados/ ganindo sonho obscuro/ sóis mecânicos/ sais agônicos"). O "fogo da estrada", percebido pelo eu poético, é a chama da "implume desencantada" trajetória que se escreve no silêncio - "sem palavra".

O último verso do poema é "desinvenção", neologismo que nos remete à capacidade inventiva do poeta frente à linguagem, assinalando que Afonso Henriques procura alternativas expressivas para figurar seu deslocamento no âmbito textual. Assim, a mudança de rumos, a decomposição e a mistura de traços exprimem a recriação da paisagem, da palavra poética e do próprio sujeito, pois a poesia atua como espaço de ambiguidades que se reconstrói a cada imagem, uma vez que se propõe a reformular objetivos e a desterritorializar posições.

Essa proposta tem várias motivações, a mais relevante relaciona-se às suas inquietações diante dos paradigmas políticos, históricos e literários disseminados no país desde a década de 60. É importante observar que as tensões da ditadura brasileira pós-68 cerceavam a liberdade artística, individual e coletiva, desencadeando preocupações com a censura, sobretudo por parte dos editores que selecionavam, com 
reservas, as obras para publicação. O pesquisador Elio Gaspari expõe os efeitos negativos do contexto sociopolítico nos tempos de repressão:

Por uma fatalidade histórica, começou em 1964 no Brasil um período de supressão das liberdades públicas precisamente quando o mundo vivia um dos períodos mais ricos e divertidos da história da humanidade. Nesse choque, duas rodas giraram em sentido contrário, moendo uma geração e vinte anos da vida nacional. (Gaspari, 2002, p.211).

As reações ao cerceamento não aconteceram apenas no Brasil, mas também em outros cenários ocidentais, em que se presenciavam as intervenções militares devido ao colonialismo em países africanos e asiáticos, além do intervencionismo econômico dos Estados Unidos nos países da América Latina. Diante desse quadro mundial, a ebulição de mobilizações em busca de abertura tornou-se uma questão representativa. A contracultura, com origem na literatura beatnik ${ }^{5}$ e no movimento hippie, influenciou muitos jovens nos anos 60 e 70, impulsionando lutas pela liberação da sexualidade, do uso das drogas e pela liberdade de expressão.

Andréa Catrópa, em sua dissertação Das margens ao infinito - a trajetória poética de Afonso Henriques Neto, observa que, além dessas questões, no território brasileiro, “a televisão, o rock, as calças jeans, a coca-cola povoavam o universo pop decisivo na

\footnotetext{
${ }^{5} \mathrm{O}$ termo beatnik é resultado da junção do radical beat - termo empregado para designar a nova geração de jovens intelectuais americanos, em meados dos anos 50, empenhada em realizar uma revolução cultural através da literatura -, com o sufixo do satélite russo Sputnik que havia sido mandado ao espaço 1957. Os principais expoentes da geração Beat foram Jack Kerouac, Willian Burroughs, Allen Ginsberg, Gregory Corso e Gary Snyder. Essa geração era considerada marginal no contexto americano, pois a palavra beat sugeria conotações negativas utilizadas entre os vigaristas, os dependentes de drogas e alguns ladrões. Diante disso, os autores beats descreviam-se como andarilhos solitários que defendiam a liberdade na linguagem e nos costumes. Tal ideologia propiciou o aparecimento das primeiras comunidades hippies no final dos anos 60 (Kerouac, 1958, p.3).
}

Brasiliana - Journal for Brazilian Studies. Vol. 3, n.1 (Jul. 2014). ISSN 2245-4373. 
formação de uma nova atitude" (Catrópa, 2007, p.36), o que demonstra o desejo de consumo, a procura incessante pela novidade e pelo excêntrico e o discurso do progresso como fatores que colaboraram com o desencadeamento de um outro olhar para a realidade circundante.

No plano literário-cultural, a crítica considerava a estética cabralina e o concretismo com seus desdobramentos como paradigmas. Heloísa Buarque de Hollanda, organizadora da antologia 26 poetas, enfatiza a "hegemonia das vanguardas, da tradição cabralina bastante influente naquele momento" (Hollanda, 1998, pp.259260), valorizando as reflexões de caráter teórico- linguístico, nas quais a valorização da forma, o significante e seus efeitos confirmavam a presença do construtivismo poético e a despersonalização na reescrita do lirismo. Embora as vertentes construtivistas pregassem o experimentalismo verbo-visual e as vanguardas apresentassem propostas de liberdade, já não correspondiam às necessidades artísticas da nova geração. Afonso Henriques, numa entrevista nos anos 90, expôs sua oposição a qualquer modelo racionalista e repressor.

Na década de 70, minha produção poética estava plena de referências contrárias a todo tipo de tirania. Naquela época, a luta contra a feroz censura da ditadura militar muito marcou a nossa geração. A adoção de uma linguagem coloquial, que retomava de certa forma alguns postulados do modernismo, junto com uma atitude profundamente crítica, cética e libertária que renegava as instâncias do poder políticoeconômico e as igrejinhas literárias - incluindo aí as vanguardas -, foram as nossas principais características. (Poesia Sempre, 1997, p.348). 
Nesse contexto, o percurso literário de Afonso Henriques Neto inicia-se com o projeto artesanal da obra O misterioso ladrão de Tenerife, publicada em 1972, tendo como coautor Eudoro Augusto. Desse modo, a publicação de seu primeiro livro ocorre, concomitantemente, com o surgimento das propostas da "geração mimeógrafo". Esta, por sua vez, reunia poetas dos anos 70 que se encontravam à margem do mercado editorial - daí o rótulo "poetas marginais" ${ }^{-}$e trabalhavam na produção e distribuição de seus livros num circuito de tiragens limitadas.

A confecção dos livros "de aspecto precário, cheios de resíduos românticos e artesanais" como assinalou Antonio Carlos Ferreira de Brito - o poeta Cacaso (Brito, 1997, p.181) -, pretendia ressaltar a condição de "não-mercadoria". Desse modo, não havia planejamento e muito menos a orientação de um designer na estruturação editorial, aparentando um folheto, uma literatura de mimeógrafo. Contudo, Afonso Henriques Neto e Eudoro Augusto, apesar da inserção cronológica na estética "marginal", demonstraram uma atenção laboriosa na construção de O misterioso ladrão de Tenerife, pois foram cuidadosos com a composição dos poemas, com a escolha do papel Kraft e da gráfica em Goiânia, com a montagem quase cinematográfica dos textos. Contaram também com o auxílio do pintor Luiz Áquila para a organização do projeto gráfico da obra. Esse trabalho feito com esmero, já apontava um Afonso Henriques "à margem da marginalidade" (Willer, 2010, p.1), na opinião do poeta Cláudio Willer, sinalizando traços de uma composição poética que se propõe a romper expectativas. Afinal, a identificação com a geração dos anos 70 ocorreu, nesse caso, apenas no que diz respeito ao critério improvisado e lúdico de escolha do título para o livro, conforme

\footnotetext{
${ }^{6}$ Favaretto explica no seu livro A invenção de Hélio Oiticica que, na literatura, o termo "marginal” foi inspirado na obra deste artista plástico que homenageava seu amigo Cara de Cavalo, considerado um fora da lei, oferecendo ao termo uma "aura às avessas" (Favaretto, 1992, p.118).
} 
afirmou o poeta em entrevista feita por Andréa Catrópa - “aquele que provocar mais gargalhada, mais riso, vai ser escolhido" (Catrópa, 2007, p.182).

O poema "Primado da explicação ou quando dói a consciência ou fragmentos de fragmentos ou", que abre o livro de 1972, faz menção a esse processo de preparo, elaboração e divulgação de $O$ misterioso ladrão de Tenerife e demonstra aspectos que se tornaram perceptíveis na escritura do poeta.

\section{PRIMADO DA EXPLICAÇÃO OU \\ QUANDO DÓI A CONSCIÊNCIA OU \\ FRAGMENTOS DE FRAGMENTOS OU}

falar das velhas pastas (portas) abertas: papéis pigmentados de tempo: velhos poemas, textos, lado a lado, selecionálos, mil estruturas e lendas, não sei: vai assim o primeiro recado, torcido, desconjuntado, a satisfação é a morte: a substância do signo: a infinita iluminação: o que vem após é o essencial: ter: de dissolvê-los, mas gravá-los em papel Kraft e espalhálos sobre a memória do mundo: desbundo: tessitura de aranhas vagarosas: vertiginosas: paralelo sonho paralelo às formações do sonho: receio que fomos sérios demais: prometo assim que da próxima vez: brasília é incrível: a especial atmosfera: esfera deixo bem claro que essas formas mal amarradas são, em todo o seu peso e densidade (em todo caso), minha própria vida (oh a minha própria vida), substância ferrosa, notdiurna: passar a viver nos labirintos dos desconhecidos cérebros por 
onde as frases já agora e sempre deslizam como um rio evaporado: tenho a considerar que da mesma forma que minhas frases vão se embebendo de vosso estrangeiro sangue, irmão para sempre irreconhecido, também vão ganhando uma nova e para mim inalcançada força, nova e para mim inalcançada força, à medida que nossas energias solidarizem-se ou não com elas, à medida que elas passem a fugir pelas tortuosas florestas das cifras e computações... (Henriques Neto, 1972, p.4).

O título do poema reporta-nos para uma multiplicidade de sentidos, sugerindo, através da conjunção alternativa $o u$, possibilidades que permanecem abertas e incertas. Do mesmo modo, a oscilação formal do texto, a disposição espacial das palavras e a pontuação também marcam a abertura, o caráter híbrido entre prosa e poesia, a imprecisão temática. As alternâncias na intitulação desse trabalho poético apresentam o projeto lírico de Afonso Henriques que oscila entre os lugares das propostas racionalistas e empíricas ("PRIMADO DA EXPLICAÇÃO OU”), os momentos de percepção subjetiva ("QUANDO DÓI A CONSCIÊNCIA OU”) e as dissoluções de instâncias, sejam elas intelectivas, sensoriais ou textuais (FRAGMENTOS DE FRAGMENTOS OU).

No poema em questão, o uso do infinitivo nos verbos "falar" e "ter" enumeram procedimentos empíricos reiterados pelo emprego de dois pontos e vírgulas que assinala a recusa de formas conclusivas no texto. Além disso, a sintaxe fragmentária, com frases espacialmente dispersas, produz um efeito tortuoso, de aspecto desconexo, mas que permite ao leitor adentrar um espaço poético aberto como "pastas"/ "portas" e experimentar as inquietações diante da ausência de um encadeamento sintático 
convencional, conduzindo-o aos descaminhos das palavras fragmentadas. É também perceptível, no poema, a presença excessiva de adjetivos e locuções adjetivas, entre os quais se destacam "velhas", "abertas", "desconjuntado", "vertiginosas", "tortuosas", termos que indicam alguns aspectos relevantes na escrita do poeta em estudo, tais como o diálogo com a poesia de outros tempos, busca de liberdade expressiva, instabilidade, valorização do veio onírico, entre outros.

Assim como foi mencionado, o poema encena, por meio de estratégias discursivas metapoéticas, a organização da obra O Misterioso ladrão de Tenerife. A escritura dos versos, o diálogo com a tradição, a transgressão, o registro idiossincrásico, a estrutura gráfica, a concretização do material literário, o lançamento independente, ou seja, procedimentos que constituem o processo lírico espacializado e lançado ao mundo através do livro.

As expressões "velhas pastas", "papéis pigmentados de tempo", "velhos poemas", "lendas", "memórias do mundo" referem-se aos indícios temporais presentes no poema. Os textos antigos, guardados nas bibliotecas, são remexidos e selecionados num movimento que escava caracteres de outros tempos. As "velhas pastas" e "velhos poemas" são revisitados e redimensionados, associando-se à abertura e à transitividade expressas pelo termo "portas" que os sucedem. As "pastas" e os "poemas" pertencem ao mesmo campo semântico de "portas", uma vez que simbolizam elementos de trânsito e de comunicação entre o interior e o exterior. Assim, retornar ao passado não significa para o poeta encaminhar-se ao fechamento e à rigidez, mas a uma possível abertura à textualidade do mundo. A direção seguida por Afonso Henriques parece ser oposta àquela priorizada pela maioria dos poetas da década de 70: "falar de velhas pastas (portas) abertas: papéis pigmenta-/ dos de tempo: velhos poemas, textos, lado a lado, selecioná-/ los, mil estruturas e lendas" (Henriques Neto, 1972, p.4). 
Nesse viés de leitura, o verbo "ter", que abre o segundo momento do poema, sugere certa obrigatoriedade, ou seja, aciona o compromisso estético do poeta ao mobilizar nas "velhas pastas" as referências "bibliotecáveis" de literatura - expressão empregada por Silviano Santiago num artigo publicado no Jornal do Brasil, em 1975, para explicitar o descuido da geração dos anos 70 pelo "valor cultural institucionalizado", ao se desvincularem do sistema editorial e da linguagem poética erudita e livresca (Santiago, 1975, p.144) - o que demonstra os caminhos opostos seguidos por Afonso Henriques. Em seguida, outros verbos o acompanham numa gradação meio desconexa. Os lexemas verbais "dissolvê-los", "gravá-los" e "espalhálos" são acompanhados de pronome oblíquo, remetendo para o objeto direto - "papéis", "poemas" e "textos" - especificado anteriormente. Tais palavras formam uma ruptura na sucessão temporal, pois a dissolução é o primeiro passo necessário ("a satisfação é a morte") para que os resíduos da tradição, dos "papéis pigmentados de tempo", sejam depurados, absorvidos, registrados e modificados em contato com outros textos, como uma espécie de experiência antropofágica.

O emprego de dois pontos no decorrer do poema constrói um elo entre os fragmentos, desempenhando a função de elementos coesivos. Desse modo, os substantivos "pastas", "portas", "papéis", "poemas", "textos", "estruturas" e "lendas" interligam-se semanticamente até se depararem com uma ruptura - "não sei" (Henriques Neto, 1972, p.4). Essa expressão, além de desestabilizar as marcas de impessoalidade, introduz a subjetividade lírica ${ }^{7}$. O verbo saber, conjugado na primeira pessoa do singular ("sei"), situa textualmente o sujeito no poema. O "não sei" inaugura a quebra da aparente comunicação, do discurso racional e linear e exprime o caráter

\footnotetext{
${ }^{7}$ É importante observar que a ausência da marcação textual do sujeito é algo recorrente nas obras de Afonso Henriques, salvo nos livros produzidos nos anos 70 e 80, em que se referencia com maior frequência a presença do eu poético.
}

Brasiliana - Journal for Brazilian Studies. Vol. 3, n.1 (Jul. 2014). ISSN 2245-4373. 
torto desta poesia, suas ambiguidades, suas desarticulações, como "o primeiro recado, torcido, desconjuntado" (Henriques Neto, 1972, p.4), ainda que a rima interna estabeleça consonância, a tessitura permanece oscilante.

As referências ao papel Kraft, utilizado na confecção do livro O misterioso ladrão de Tenerife, e à cidade de Brasília explicitam a tensão entre vida e linguagem ficcional, entre biografia e encenação da memória, questões preponderantes nas produções literárias dos anos 70 do século $\mathrm{XX}$, haja vista os tons quase confessionais, a aproximação ao cotidiano, a opção pelos diários e as alusões ao corpo que propiciavam confusões entre as subjetividades autorais e poéticas. Sobre isso, escreve Flora Sussekind:

E se as relações entre os no máximo 500 leitores de cada tiragem destes livros feitos artesanalmente e seus autores se estreitam pelo contato pessoal na hora da venda, no texto procura-se intimidade semelhante. Daí, o tom diário (pessoal ou geracional) de grande parte da poesia produzida nas últimas décadas no país. Ela parece obedecer a essa experiência quase amorosa de um tom íntimo, caseiro, no texto poético, assim como do autor se exige certo charme para que consiga vender seus livros mais facilmente. (Sussekind, 2004, p.125).

Nesse entrelaçamento entre vida e arte, o poeta consegue dramatizar as experiências concretas de composição desse livro de pontuais afinidades com a geração de 70, porém sem perder a consciência de que nas brechas dos "velhos poemas" também se configura seu trabalho poético. O discurso de Afonso Henriques Neto ratifica os dados biográficos presentes no texto, conforme salienta o próprio poeta numa entrevista feita para a 
Azougue Editorial, demonstrando os esforços para a edição de sua primeira publicação que, de certa forma, foram recompensados pelo olhar favorável dos literatos da época.

Em 1969 resolvi publicar meu primeiro livro. A época era a do AI-5, ditadura braba. O poeta Eudoro Augusto era um amigo meu lá de Brasília que enfrentava as mesmas dificuldades: se já é difícil editar poesia em tempos normais, ficava impossível quando se acrescenta o medo das editoras em publicar algo político sob ditadura feroz. Resolvemos juntar nossos trabalhos em um só livro, dispusemos os textos na forma de um diálogo, algo próximo à montagem cinematográfica (o cinema era também um interesse comum), compramos papel Kraft, colocamos em uma caminhoneta e fomos para Goiânia rodar o livro [...]. Todo esse processo durou mais de um ano, e o livro só saiu no final de 1971, quando eu e o Eudoro estávamos de mudança para o Rio de Janeiro: íamos trabalhar na equipe da enciclopédia Mirador Internacional, capitaneada por Antônio Houaiss. (Henriques Neto Apud Catrópa, 2007, p.18).

Ao se retomar o poema "Primado da explicação ou quando dói a consciência ou fragmentos de fragmentos ou", nota-se uma outra cisão com o fragmento "a satisfação é a morte" que parece anunciar a supressão dos limites, sobretudo as marcas temporais, pois "que vem após é o essencial" (Henriques Neto, 1972, p.4). A atmosfera filosófica toma conta do poema por meio da equivalência dos termos "morte", "substância", "iluminação", "essencial", na tentativa de se pensar a tradição e a ruptura como duas 
faces da mesma moeda. Ambas são substanciais para a construção poética, iluminam, obscurecem, nascem e morrem no mesmo espaço escritural.

Ao seguir a organização do poema, observa-se que o trabalho fônico e as escolhas lexicais entretecem-se num ritmo lento e particular, em oposição à agitação urbana e à ideologia progressista instaurada em Brasília. Ao poeta cabe trabalhar os fios textuais, tecê-los atentamente com a mesma visceralidade e liberdade das construções oníricas. Assim, tramar o poema ("tessitura de aranhas"), projetar o livro pode ser "paralelo sonho paralelo às formações do sonho" (Henriques Neto, 1972, p.4). Contudo, avaliando seu contexto, o sujeito une-se à coletividade e reconhece "receio que fomos sérios demais". A postura subjetiva eclode do momento reflexivo e o eu poético dribla o "primado da explicação".

O texto traz ainda o tom de conversa com o leitor inserido através do fragmento "deixo bem claro", reforçando a presença do sujeito lírico nas "formas mal amarradas", ou melhor, na tessitura fragmentada com a qual Afonso Henriques encena a própria vida, valendo-se de um registro ironicamente performático ("oh a minha própria vida"). Tanto a relação arte- vida quanto os traços mineiros da "substância ferrosa" são problematizados pelo poeta e postos em tensão com o neologismo "notdiurna", o que ressalta a capacidade de experimentar as luzes e as sombras, o desvelar e o revelar, o concreto e o abstrato, marcas indissociáveis da palavra poética na obra do referido autor.

Nos últimos fragmentos do poema, a feitura do livro ressalta outra questão relevante. Trata-se, agora, de pensar a recepção da obra literária, o trajeto fluido das palavras "nos labirintos dos desconhecidos cérebros por onde frases já agora e sempre deslizam como o rio evaporado" (Henriques Neto, 1972, p.4). Nesse sentido, o leitor/ ouvinte adquire um papel ativo diante do mundo-texto, modificando-o nas 
refigurações ${ }^{8}$, no processo de interação entre texto e receptor, e dando-lhe nova e "inalcançada força".

O próprio poeta posiciona-se como autor e leitor. Ao se apropriar de experiências textuais do outro, escreve e reescreve a poesia, constituindo relações com o texto através do processo de leitura. Assim, o pronome possessivo "vosso" evidencia o emprego da construção erudita "vosso estrangeiro sangue" e esboça as escolhas intelectuais do poeta ao se referir implicitamente a uma passagem do poema "Au lecteur", de Charles Baudelaire: “Tu connais, lecteur, ce mostre délicat,/ - Hypocrite lecteur, - mon semblable, - mon frère!"9 (Baudelaire, 2006, p.112). Através dessa relação, Afonso Henriques aponta a atitude antropofágica de absorver a textualidade alheia e transformá-la no próprio espaço poemático. Do mesmo modo, o leitor capta as palavras do poeta mineiro, tornando-se capaz de revesti-las de diferentes sentidos: "[...] da mesma forma que minhas fra-/ ses vão se embebendo de vosso estrangeiro sangue, irmão para sempre irreconhecido, também vão ganhando uma nova e para mim incansável força" (Henriques Neto, 1972, p.4). Autor e leitor experimentam a ambiguidade da poesia e forjam uma proximidade.

Assim, o sujeito poético configura-se em diálogo com o outro, pois o eu e o outro se convertem em nós - "nossas energias". Numa aparente aproximação, ambos perscrutaram as possibilidades linguísticas que se deslizam "pelas tortuosas florestas" e permanecem inconclusas. As reticências que "encerram" o texto retomam a abertura proposta pelo título do poema. Os cortes e os fragmentos ao longo desse trabalho

\footnotetext{
${ }^{8} \mathrm{O}$ conceito de refiguração foi empregado por Paul Ricouer em Tempo e narrativa, considerando que, no âmbito da leitura, o ato de reconfigurar "marca a interseção entre o mundo do texto e o mundo do ouvinte ou do leitor" (Ricouer, 1994, p.110).

${ }^{9}$ Teu conheces, leitor, o monstro delicado/ - Hipócrita leitor, meu igual, meu irmão! (tradução de Ivan Junqueira, 2006, p.113).
}

Brasiliana - Journal for Brazilian Studies. Vol. 3, n.1 (Jul. 2014). ISSN 2245-4373. 
escritural criam um universo fraturado e traçam um lirismo que oscila por entre os ecos das palavras de muitos outros.

Como se pode ver, esse poema "Primado da explicação ou quando dói a consciência ou fragmentos de fragmentos ou", publicado em 1972, apresenta o lírico em Afonso Henriques que, além de oblíquo, se abre para o diálogo com muitas vozes, dentre as quais estavam aquelas sincronizadas no mesmo contexto de produção poética. Vale ressaltar que essas vozes eram distintas entre si, ainda que o próprio poeta Cacaso defendesse a ideia de que a poesia "marginal" formava um poema coletivo - o "poemão escrito por várias mãos" (Brito, 1997, p.13).

Sobre esses poetas, pairava a "sensação de 'emparedamento"” 10, de um lado "por Drummond e Cabral e de outro pelos concretos", criando um "impasse criativo" (Moriconi, 2002, p. 125) na expectativa da produção do novo. Grande parte deles aderiu a uma poesia de estilo descompromissado e, às vezes, com certo descuido em relação à linguagem. Muitos apostavam no lúdico, na rapidez e na ironia do poema-piada que aparentemente parecia aproximar autor e leitor. Eles também incorporavam a "poética do coloquial" (Hollanda, 1998, p.10) irônica e ambígua, a informalidade, as pitadas de humor, recusando, ou melhor, encenando uma oposição ao intelectualismo e aos valores convencionais das estéticas clássicas, o que, de algum modo, remete às inovações do Modernismo de 22. Além disso, propunham uma recusa às técnicas de construção, às posturas formalistas, selecionando as máscaras de desintelectualização em seus poemas. Chacal, um dos poetas inserido nesse circuito poético, partilha sua experiência de estar à margem do sistema:

\footnotetext{
${ }^{10}$ Emparedamento é uma expressão utilizada por Ana Cristina Cesar e Afonso Romano de Sant'Anna para designar a ansiedade dos poetas diante da busca do novo, uma vez que não havia horizontes significativos apontados pela crítica literária que privilegiava a recepção do cânone (cf. Moriconi, 2002, p.125).
}

Brasiliana - Journal for Brazilian Studies. Vol. 3, n.1 (Jul. 2014). ISSN 2245-4373. 
O poema curto e enigmático, herança do Oswald, usado por mim, era uma forma de passar rápido uma ideia. Naquela época tudo tinha que ser rápido. A vertigem da idade, a polícia nos calcanhares. Acho que encarnei bem o distúrbio do período, criando, produzindo, distribuindo farpas certeiras a torto e a direito. (Apud Brito, 1997, p. 358).

O caráter dissonante e assimétrico dessa poesia levou a crítica literária a encontrar dificuldades de compreendê-la. A ideia de periodização e o olhar homogêneo não configuravam critérios satisfatórios para julgamento, uma vez que os novos poetas opunham-se a quaisquer rótulos conceituais. Duas décadas após a releitura da antologia 26 Poetas, Heloísa Buarque de Hollanda pontua a tendência eclética da poesia naquele momento.

O que realmente me atraiu nesse material não foi a unidade que eu dizia procurar ao defini-lo para justificar o conjunto dos participantes da antologia, mas, muito pelo contrário, o claro direito ao dissenso que este material começava a reivindicar em nossa produção cultural. A variedade de estilos, projetos e crenças que encontrei nesta última releitura dos 26 me encantou. (Hollanda, 1997, p.345).

O comentário de Heloísa Buarque de Hollanda demonstra que uma revisão de sua análise fez-se necessária, já que, assim como outros críticos, reiterou denominações como "movimento", "geração marginal" ou ainda "geração mimeógrafo", entre outras, cujas considerações almejavam situar essas produções marcadas pela heterogeneidade e por traços distintos. Do mesmo modo, tais tentativas de incorporá-las sob uma 
perspectiva homogênea levaram a crítica a radicalizar seus juízos acerca da poesia no circuito dos anos 70 .

A "variedade de estilos e de projetos" foi avaliada pelos críticos como “lixeratura" (Sant'Anna, 1976, p.59), "viagem egolátrica" (Lima, 1976, p.126), "não exatamente literatura, mas intimidade, confissão" (Sussekind, 1993, p.67), "poesia ruim", "atitude antiliterária", "veículo acrítico e desqualificado de expressão" (Dantas e Simon, 1987, p.95), em prol de uma "modernidade pensada em abstrato, independentemente dos processos sociais, econômicos, técnicos, urbanos que estavam de fato em andamento" (Dantas e Simon, 1987, p.31).

Como se percebe, os críticos citados questionavam a supervalorização da subjetividade, o excesso de coloquialismo, a abordagem de experiências imediatistas e superficiais e o processo de desliteralização da poesia, afirmando que esses elementos assinalavam a ausência de um programa estético crítico e articulado. No artigo "A literatura no retalho", publicado no jornal Movimento, de 1976, Flávio Aguiar ironiza a potencialidade literária dessa poesia, dizendo que "ao chegar à antologia, o poeta está a um passo da academia, e depois disso só sebo de livros" (Aguiar, 1976, p.173).

Por outro lado, Heloísa Buarque de Hollanda justifica que mesmo enquanto "poesia não-literária", essa produção mostrava-se preocupada "com a ideia canônica de poesia" (Hollanda, 1998, p.344), argumentando que o ecletismo dos poetas explicitava recusa a projetos estéticos pré-definidos, como já havia realizado o movimento modernista de 22. Carlos Alberto Messeder Pereira, de algum modo, concorda com Heloísa, pois acredita que a liberdade defendida pelas produções independentes questionava os valores dos sistemas editoriais e as funções dos intelectuais e da própria literatura (Pereira, 1981, p. 18). Além disso, interrogava também as formas de recepção promovidas por esse circuito cultural da década de 70, já que os leitores dessa geração 
pareciam absorver a aura de marginalidade que envolvia os poetas. Segundo Flora Sussekind, a poesia considerada "marginal", ao invés da construção, privilegiava a expressão, destacando uma linguagem dessacralizada e priorizando o gosto do leitor.

E, para obter esse efeito de reconhecimento imediato, essa resposta direta ao leitor, foi preciso que o texto poético começasse a dialogar cada vez mais com os media e menos com próprio sistema literário, cada vez mais com o alinhavo emocional do diário, com o instantâneo, com o registro, em close, da própria geração. A biblioteca deixa de ser o lugar por excelência do poeta e o seu país é o mass media, diz Silviano Santiago em 1975. E é entre referências cada vez mais frequentes ao universo da televisão, da propaganda, dos quadrinhos, dos jornais populares, canções de sucesso e o detalhado relato do que se passa na rua, no cotidiano desses poetas sempre em trânsito que se vai estabelecendo um novo tipo de pacto, menos literário e mais confessional com o leitor. (Sussekind, 1993, p. 74 - grifos da autora).

As mudanças nas formas de circulação do texto poético são, de certo modo, o fator mobilizador de novo pensamento acerca de poesia nos anos 70, pois os livros eram comercializados pelos próprios poetas num corpo a corpo com seus leitores no circuito cultural e na boemia urbana, sobretudo no Rio de Janeiro. O próprio Afonso Henriques afirmou em entrevista que o lançamento e a distribuição de seu primeiro livro aconteceram numa pizzaria em Ipanema: "Foi um lançamento, puro e simples, em cima das mesas da pizzaria, com os pacotes (dos livros) colocados no chão, que nós levamos 
embaixo do braço. Não tinha editora, não tinha nada... Éramos nós com aqueles pacotes" (Catrópa, 2007, p.184).

Entretanto, a partir dos anos 80, quando alguns desses autores filiaram-se às editoras vigentes no país, surgiram outros critérios de valorização da obra literária. Esses critérios não se baseavam somente em padrões estéticos, mas principalmente na lógica do mercado. Diante de tais mudanças, Flora Sussekind enfatiza que os escritores submeteram-se a um "processo de profissionalização inédito em termos de vida literária brasileira" e começaram, "em maior número, a 'viver de literatura'" (Sussekind, 2004, p.149). Sendo assim, exigia-se um novo tipo de intelectual, 'um intelectual de divulgação', "com um pé no verniz acadêmico e outro na dicção jornalística" (Sussekind, 2004, p.153). Por esse motivo, Ítalo Moriconi aponta, como traço marcante na geração de 1980, a atitude de "reliteralização", já que a volta ao livro, ou melhor, à sofisticação da produção livresca significava a "recuperação do valor propriamente literário da literatura" (Moriconi, 1998, p.19).

Por outro lado, nota-se que os escritores da década de 70 encenavam a resistência às impregnações literárias, esboçando uma posição fluida e desarticulada diante das mesmas. Essa teatralidade é perceptível em poetas como Cacaso, Ana Cristina César, Eudoro Augusto, Francisco Alvim, entre outros nomes, uma vez que, embora demonstrassem descaso com certas retóricas de poesia, ativavam as vozes de Drummond, Bandeira, Mário e Oswald de Andrade, apresentando a força lírica da expressão aliada à consciência técnica na construção dos poemas. Desse modo, percebese que mesmo a tentativa de originalidade e de ruptura não consegue excluir na sua totalidade as marcas discursivas da tradição. É com base nela que o lirismo é reescrito e o discurso poético adquire traços distintivos. No que se refere a Afonso Henriques, 
alguns estudiosos de literatura destacaram a presença de um "vezo literário" como elemento que o distinguia no cenário cultural dos anos 70.

[...] há exemplos de poetas que compartilham de traços característicos da produção marginal, ao mesmo tempo que apresentam acentuado vezo literário, denotando uma informação qualificada. Digamos que, por esta veleidade mesma, a poesia de Geraldo Carneiro, Afonso Henriques Neto e Eudoro Augusto tem menos interesse do que a trivial desliteralização marginal. (Dantas e Simon, 1987, p. 103).

Iumna Simon e Vinícius Dantas, ao analisarem as diferenças e semelhanças do estilo poético de alguns autores desse período, citam Afonso Henriques entre os que preservaram seus traços "bibliotecáveis" e uma preocupação estética com a composição poética. Entretanto, ressaltam que esses traços não apresentavam tanta relevância para o leitor acostumado à "trivial desliteralização marginal".

Diante disso, verifica-se que o desejo de liberdade verbo-visual foi o que o aproximou do circuito poético na década de 70. Afonso Henriques, numa entrevista concedida a Heloísa Buarque de Hollanda, comentou a relevância de circular livremente por qualquer tipo de expressão literária, confirmando que "o sentimento e a linguagem poéticas serão sempre jovens, como jovem é a lírica de Safo escrita há três milênios" (Hollanda, 1998, p.350).

No livro Avenida Eros, Afonso Henriques explicita seu diálogo com os autores considerados canônicos pela crítica, aproximando o clássico e o contemporâneo, através de citações e de homenagens a Pound, a Octavio Paz, a Murilo Mendes, a Pedro Nava, a Drummond, a Heráclito e a Borges. Em meio ao boom de poesia na década de 1970, o 
poeta não abre mão do "vezo literário", desde que a liberdade seja o fio condutor em seus poemas. No poema "não seja tão literário", inserido na obra Abismo com violinos, de 1995, há menção às linhas de força que constituem a poética de Afonso Henriques.

não seja tão literário

mas se homero dante a bíblia

são pura literatura

por que não escrever abismos com violinos?

(sei que minha geração

ainda mais uma vez ironizou

os programas do poder

os discursos literários

romantismos concretismos

panfletismos cabotinismos

evoé nuvem cigana

saudades cacaso \& ana

mais tantos que sonharam o fim das ditaduras

naqueles roarin'70)

e o consolo paralelo

das construções diamantinas

o la chair est triste, helás!

et j'ai lu touts les livres

(não resolve

mas me ilumino de imenso)

última oportunidade a um cinquentão 
sem poética consistente

mas com tanta vodka pela frente

(se pudéssemos estrangular deus

a branca medicina

tudo tudo

ironia na neblina)

a prosa invadiu de vez a poesia

com música ou sem melodia

o verso não mais recamará ossos

(parcas as parcas

aspérrimos verbos e este ônibus

seco)

corais de luzes dolorosas

navios do princípio do tempo

encalhados nos esqueletos sem fim

(ninguém virá estrada para

e se vier não há mais jeito

refulgem ruíssimas retinas

o anjo se drogou todo de estrelas)

no fundo fosso a fera engole

a ferida tremenda

e no entanto a vida

entanto o sonho

(virá cantando aleluia pelo atalho

todos desconhecem o mapa mágico 
rastro sagrado pedra angular

tudo se esqueceu)

última oportunidade hare

hare (Henriques Neto, 2001, pp.179-180)

O poema inicia-se com um tom de conselho, "não seja tão literário", que, em seguida, é desestabilizado com o questionamento "por que não escrever abismos com violinos?". Tal pergunta sucede a enumeração de nomes consagrados na história da literatura ocidental ("mas se homero dante a bíblia/ são pura literatura") que, embora entranhada no poeta, se torna alvo de inquietação, pondo em questão os parâmetros legitimadores de uma obra literária. É válido observar que as referências clássicas citadas são registradas com iniciais minúsculas, o que implica inserir a leitura do cânone no mesmo patamar de outras experiências do sujeito em relação à linguagem. Nesse movimento interrogativo, surgem discussões sobre a linguagem, a forma, o tempo e o espaço, ou seja, reflexões acerca dos sentidos de se produzir poesia. A expressão "abismos com violinos" refere-se ao livro do autor em estudo, publicado em 1995, pelo editor Massao Ohno.

Os parênteses empregados no poema, ora abrem espaços para a memória, ora para as reflexões. É por meio deles que o sujeito poético inicia sua viagem pelos "roarin'70". A proximidade identitária com essa geração é assinalada pelo pronome "minha", ainda que o sujeito poético procure o lugar incomum. A recusa dos poetas considerados "marginais" aos discursos literários homogeneizadores ("romantismos concretismos/ panfletarismos cabotinismos") e aos "programas de poder" torna-se também motivo de indagação. A memória novamente é ativada e nela ecoam os nomes de Cacaso e Ana Cristina César, referências significativas de uma geração, autores que 
mesmo ao abraçar a rebeldia, as transgressões e a linguagem cotidiana, não desprezaram a leitura permanente e a recriação de suas bibliotecas.

Num momento similar, Afonso Henriques traz à cena poética o grupo da Nuvem Cigana, formado pelos jovens artistas Charles, Chacal, Ronaldo Bastos, Guilherme Mandaro, Bernardo Vilhena e Ronaldo Santos. No texto, o grupo é saudado por um grito festivo da Antiguidade - "evoé" - com o qual se evocava Baco durante as orgias. A interjeição "evoé" associa-se ao ideário dionisíaco da contracultura, na década de 70. Os delírios, a desordem, o exílio, as experiências com drogas e a liberação do corpo adentraram a poesia como objeto lúdico de arte.

Em trajeto paralelo, encontra-se o trabalho oficinal figurado nas "construções diamantinas". Contudo, tanto a expressividade "marginal" quanto o construtivismo poético tornam-se objetos de reflexão para o poeta em sua escrita lírica. De todo modo, a única certeza é que a poesia "não resolve", mas o eu poético consola-se com a iluminação transmitida pela experiência da leitura - "mas me ilumino de imenso"11. Os livros lidos - "a pura literatura" - não oferecem alicerces para a compreensão de todos os sentidos, mas se tornam elementos motivadores para o sujeito.

Afonso Henriques costura, no poema, os versos de "Brise Marine" escritos por Mallarmé - "la chair est triste, helás!/ et j'ai lu touts les livres". A inserção do poeta francês no poema "não seja tão literário" destaca o lugar da leitura na proposta poética de Afonso Henriques, como algo que o posicione em outro topos que não se restrinja aos dois polos: "burilamento de diamantes e o afastamento das convenções literárias e poemáticas" (Santos, 2006, p.48). A condição gauche do lirismo de Afonso Henriques está

\footnotetext{
${ }^{11}$ O verso "mas me ilumino de imenso" foi empregado anteriormente pelo poeta Giuseppe Ungaretti, no poema "Manhã" formado apenas pelo dístico "Ilumino-me/ de imenso". Ungaretti foi um nome relevante para a literatura italiana em meados do século XX.
}

Brasiliana - Journal for Brazilian Studies. Vol. 3, n.1 (Jul. 2014). ISSN 2245-4373. 
justamente na inquietude de fixar sua poesia num desses polos, pois ele transita por eles sem pertencer a nenhum.

Em “Brise Marine”, Mallarmé põe-se a viajar pela linguagem. A liberdade é sua expectativa maior, almejando o impreciso, o informe. Transcreve-se aqui o primeiro fragmento do poema:

La chair est triste, helás! et j'ai eu lu tous les livres

Fuir! là-bas fuir! Je sens que des oiseaux sont livres

D'être parmi l'écume inconnue et les cieux!

Rien, ni les vieux jardins reflétés par les yeux

Ne retriendra ce coeur qui dans la mer se trempe

Ó nuits! Ni la clarté déserte de ma lampe

Sur le vide papier que la blancheur défend

Et ni la jeune femme allaitant son enfant.

Je partirai! Stemaer balançant ta mâture

Lève l'ancre pour une exotique nature! ${ }^{12}$

(Mallarmé, 2005, p.48)

No poema "Brise Marine", tem-se uma escrita bem distante dos traços do construtivismo poético evidenciado em Un Coup de Dés. Há a presença de um primeiro momento da obra de Mallarmé, relacionado ao estilo parnaso-simbolista, numa

\footnotetext{
${ }^{12}$ Reproduz-se aqui fragmento do poema traduzido por Álvaro Cardoso Gomes, no livro O Simbolismo: “A carne é triste, ai!, e eu li todos os livros./ Fugir! Para o além fugir! Sinto que os pássaros são ébrios/ De estar no meio da espuma desconhecida e dos céus!/ Nada, nem os velhos jardins refletidos pelos olhos/ Não reterá este coração que no mar se umedece/ Ó noites! Nem a claridade deserta de minha lâmpada/ Sobre este papel vazio que a brancura protege/ e nem a jovem mulher a amamentar seu filho./ Eu partirei! Barco a vapor a balançar teus mastros/ Levanta a âncora para uma exótica natureza!" (Gomes, 1994, p.25).
}

Brasiliana - Journal for Brazilian Studies. Vol. 3, n.1 (Jul. 2014). ISSN 2245-4373. 
linhagem próxima a de Baudelaire. Nesse sentido, Afonso Henriques ao recuperar esta fase do poeta francês e ao trazê-la para o poema, parece não destacar a "poesia pura", a "arte pela arte" ou até mesmo as palavras lançadas no branco da página, mas ressaltar o aspecto cambiante do referido autor na procura de rumos para a poesia - "Sur le vide papier que la blancheur défend".

Como enfatiza Paul de Man, em O Ponto de vista da cegueira, não se pode negar a importância de Mallarmé para a lírica moderna, uma vez que, além do ato de escrita gerar reflexões acerca de sua origem e de suas potencialidades criativas, "abre um ciclo de questões que nenhum de seus verdadeiros sucessores se pôde esquecer" (Man, 1999, p.41). O autor chama atenção para a "obliquidade irônica" de Mallarmé, que com suas ondulações e retórica de crise sinalizava a necessidade de um outro discurso para a modernidade poética, longe da cegueira da crítica e de sua tendência a automistificação diante de um tempo de desordens.

As oscilações no poema "Brise Marine" parecem provocar efeitos na escrita de Afonso Henriques. Desse modo, envolvido pelo movimento mallarmaico, o poeta experimenta os efeitos da lírica cambiante em busca do "écume inconnue", do "là-bas", da "exotique nature" da linguagem, a fim de construir um caminho diferenciado em relação aos "roarin'70" e àqueles definidos pelas "construções diamantinas". A viagem proposta por Mallarmé conduz o poeta ao cerne da questão "por que não escrever abismos com violinos?", levando-o a entrecruzar suas experiências linguísticas e intelectuais, com o intuito de abrir espaços para novos horizontes poéticos. A instabilidade de seu projeto literário é ratificada textualmente através da referência à sua condição de "sem poética consistente", o que o leva a enfatizar o manejo livre da poesia e da ruptura com possíveis modelos que proponham cristalizar seu discurso. Essa liberdade configura-se 
como o objetivo fulcral daquele que escreve e encena-se no universo textual ("um cinquentão/ [...] mas com toda vodka pela frente").

Segundo Andréa Catrópa, em leitura atenta da poesia do referido autor, feita no artigo "Das margens ao infinito - a trajetória poética de Afonso Henriques Neto", seu “estilo oscila entre o sublime e o prosaico, entre o transcendental e o cotidiano, demonstra que o caminho trilhado pelo autor não resvala na linearidade" (Catrópa, 2005, p.594). O poeta se propõe a construir uma dicção própria, uma vez que se permite transitar por tendências díspares. Sua poética apresenta estruturas híbridas, há momentos em que prosa e poesia dividem espaços gráficos. No livro Os gêneros literários, Yves Stalloni comenta que essa hibridização dos gêneros é perfeita "para se adaptar às metamorfoses e às inovações da poesia contemporânea, preocupada em exprimir pela escrita sua tenaz aspiração à liberdade" (Stalloni, 2001, p.168). Essa experiência livre com a palavra é almejada pelo poeta, ainda que "navios do princípio do tempo/ encalhados [...]" sejam obstáculos no transporte para uma escrita fluida e sem limites.

Entre a "ferida tremenda" e a "vida", elementos opostos e próximos, o poeta ensaia o sonho, a escritura poética. A liberdade onírica concretizada na linguagem torna-se "última oportunidade", o atalho para o desconhecido "mapa mágico/ rastro sagrado pedra angular", ou seja, a poesia. O poema encerra-se com a expressão "hare hare", mantra utilizado pelos seguidores da corrente filosófica Hare Krishna, relevante para os adeptos da contracultura na década de 70. Esta meditação mântrica, inserida no poema com certa ironia, sugere relações entre morte e libertação, aponta a constante busca de um equilíbrio de tais limiares aparentemente díspares. Nesse sentido, a poesia torna-se lugar de tensões, no qual o sujeito experimenta, através do texto, o confronto dos limites entre a vida e a morte, o real e o imaginário, a palavra e o silêncio: "nada existe, celebremos/ a alegria./ o nascer e o morrer/ não nos acontece./ só para os outros 
somos espetáculos." (Henriques Neto, 1995, p.13). Seja por um viés beat, baudelairiano, mallarmaico, seja por traços experimentais, seja por um tom visionário, o lirismo do poeta mineiro configura um sujeito também errante em face de si e do mundo.

Se os poetas dos anos 70 encenavam o repúdio à produção intelectualizada e a intimidade com o leitor, Afonso Henriques investia cada vez mais numa poética oscilante. Assim, a busca de liberdade é o projeto maior no lirismo do autor, conduzindo-o à errância, à postura gauche, às relações ambivalentes entre palavra poética criadora e palavra cotidiana: “carne ou metáfora - não importa -/ sendo nada tudo alcança:/ o poeta é a viagem/ mesmo contra a esperança" (Henriques Neto, 1995, p.92). O poeta é sujeito em trânsito. É viajante por entre os efeitos líricos da interação entre criação e técnica, oriundas dessa transfusão de mão dupla presente em sua escrita poemática. No jogo entre o domínio do ofício do verso e a expressividade, o poeta expõe que o ato de escrever poesia exige reflexão constante, pois se trata de articular linguagens, ativando a criatividade e a capacidade de reinvenção, que dão a ver as tensões entre presença e ausência, totalidade e vazio, conhecimento e sensibilidade.

Como se pode perceber, o caráter multiforme da poesia de Afonso Henriques é motivado pelo desejo do excessivo e do ilimitado, o que explicita a diversidade e a ruptura de expectativas. É nessa multiplicidade de formas, vozes e afetos que o poeta se desterritorializa, de modo a experimentar os desafios, os desvios e as aproximações através de caminhos distintos. Dessa forma, seu lirismo inscreve-se em direção ao fluxo contínuo, verbal e imagético que, em determinados momentos, encontra-se com o silêncio, com a ausência, mas não deixa de mobilizar a revitalização da palavra poética. 


\section{Bibliografia}

Aguiar, Flávio. “A literatura no retalho”. In: Jornal Movimento, São Paulo, 12 jul., 1976.

Andrade, Carlos Drummond. Antologia Poética. Rio de Janeiro: Record, 1996.

Baudelaire, Charles. As Flores do Mal. Rio de Janeiro: Nova Fronteira, 2006.

Brito, Antônio Carlos de. Não quero prosa. Campinas e Rio de Janeiro: Ed. Unicamp e Ed. UFRJ, 1997.

Catrópa, Andréa. "Das margens ao infinito - a trajetória poética de Afonso Henriques". In: Anais dos Estudos Linguísticos XXXV, São Paulo: USP, 2005, p.592-597.

. Das margens ao infinito - a trajetória poética de Afonso Henriques Neto. Dissertação

de Mestrado em Teoria Literária e Literatura Comparada. São Paulo: USP, 2007, 211 p.

Dantas, Vinícius \& Simon, Iumna Maria. "Poesia Ruim, Sociedade Pior". In: Remate de Males. Campinas, 1987.

Dictionnaires Le Robert. Paris: Société de Dictionnaires Le Robert, 2007.

Favaretto, Celso. "Impasses da Arte Contemporânea". In: AJZENBERG, E. (org.).

Comunicações e Artes em Tempo de Mudança - Brasil, 1966-1991. São Paulo: ECA USP/SESC, 1992.

Freitas Filho, Armando. "Poesia viva". In: NOVAES, Adauto (org.). Anos 70 - ainda sob a tempestade. Rio de Janeiro: Aeroplano/ Senac, 2005.

Gaspari, Elio. A ditadura envergonhada. São Paulo: Cia das Letras, 2002.

Gomes, Álvaro Cardoso. O Simbolismo. São Paulo: Ática, 1994.

Henriques Neto, Afonso \& Augusto, Eudoro. O Misterioso Ladrão de Tenerife. Brasília/ Goiânia: Edição do autor, 1972. . Abismo com violinos. São Paulo: Massao Ohno Editor, 1995. 
. Ser infinitas palavras (poemas escolhidos \& versos inéditos). Rio de Janeiro: Azougue Editorial, 2001.

Hollanda, Heloísa Buarque. Esses poetas: uma antologia dos anos 90. Rio de Janeiro: Aeroplano, 1998.

Kerouac, Jack. “About the Beat Generation”. In: Esquire. New York, março de 1958.

Lima, Luiz Costa. “Poesia Hoje”. In: Revista José, Rio de Janeiro, 31 ago. 1976.

Mallarmé, Stéphane. Poésies et autres textes. Paris: Libraire Générale Française, 2005.

Man, Paul de. O ponto de vista da cegueira - Ensaios sobre a Retórica da Crítica Contemporânea. 2. ed. Lisboa: Edições Cotovia, 1999.

Man, Paul de. O ponto de vista da cegueira - Ensaios sobre a Retórica da Crítica Contemporânea. 2 ed. Lisboa: Edições Cotovia, 1999.

Moriconi, Ítalo. "Quatro (2+2) Notas sobre o sublime e a dessublimação". In: Revista de Literatura Comparada. Florianópolis: ABRALIC, n.4, 1998, pp.103-116.

. Como e por que ler a poesia do século XX. Rio de Janeiro: Objetiva, 2002.

Pereira, Carlos Messeder. Retrato de Época: Poesia Marginal - anos 70. Rio de Janeiro: Funarte, 1981.

Revista Poesia Sempre - Poéticas do pós-moderno. Rio de Janeiro, n.8, 1997.

Ricouer, Paul. Tempo e narrativa. 1 v. Campinas, São Paulo: Papirus, 1994.

Sant'Anna, Afonso Romano de. “Os Sórdidos”. In: Revista Veja. 7 jul., 1976.

Santiago, Silviano. "Poesia jovem: roteiros de velhas vanguardas, à tropicália, ao marginal mimeografado". In: Jornal do Brasil, Rio de Janeiro, 20 dez. 1975.

Santos, Marcelo dos. Murmúrio das sombras: aspecto do noturno na poesia de Afonso Henriques Neto. Dissertação de Mestrado em Literatura Brasileira. Rio de Janeiro, UERJ, 2006, 151 p.

Brasiliana - Journal for Brazilian Studies. Vol. 3, n.1 (Jul. 2014). ISSN 2245-4373. 
Stalloni, Yves. "A poesia e o gênero lírico". In: __. Os gêneros literários. Rio de Janeiro: DIFEFIL, 2001.

Sussekind, Flora. Papéis colados. Rio de Janeiro: UFRJ, 1993.

. Literatura e vida literária: polêmicas, diários e retratos. 2 ed.. Minas Gerais: Editora UFMG, 2004.

- “Desterritorialização e forma literária. Literatura brasileira contemporânea e experiência urbana". In: Literatura e sociedade. Revista do Departamento de Teoria Literária e Literatura Comparada - USP. São Paulo: USP, n.1, 2005, pp.60-81.

Villaça, Alcides. Passos de Drummond. São Paulo: Cosac \& Naify, 2006.

Willer, Cláudio. "Afonso Henriques Neto, um poeta à margem da marginalidade". In: Agulha. Fortaleza/ São Paulo, out. de 2010. 